\section{Potato Genotypes Differ in Petiole Nitrate-nitrogen Concentrations Over Time}

\author{
Randy J. Lewis ${ }^{1}$ and Stephen L. Love \\ Aberdeen Research and Extension Center, University of Idaho, Aberdeen, \\ ID 83210
}

Additional index words. Solarium tuberosum, fertility, petiole analysis

\begin{abstract}
Petiole $\mathrm{NO}_{3}-\mathrm{N}$ concentrations (PNCs) of seven potato (Solanum tuberosum $\mathrm{L}$.) genotypes grown under four $\mathrm{N}$ treatments were studied. In 1986-88, the cultigens were planted in plots with a gradient of available $N$ created by adding $0,140,280$, or $420 \mathrm{~kg} \mathrm{~N} /$ ha ammonium nitrate split between preplant and periodic seasonal applications. PNCs were significantly $(P \leq 0.05)$ affected by year, sampling time (four times per season), $\mathrm{N}$ rate, and cultigen. All first- and second-order interactions were also significant $(P<0.05)$. The relative PNC ranking among cultigens remained nearly constant across years when averaged across sampling dates and $\mathbf{N}$ rates. Regression-equation distinctiveness for each cultigen relating PNC to sampling time demonstrated a genotypic influence on seasonal PNC and allowed separation into four response classes. Using a data subset consisting of the 1988 trial, an optimal $\mathrm{N}$ rate was determined and regression equations were computed relating PNC to sampling date for each cultigen at the applied $N$ rate nearest to the optimum. Tests for distinction separated the equations of the seven cultigens into six unique classes; 'Frontier Russet' and 'Ranger Russet' equations were coincident.
\end{abstract}

Proper $\mathrm{N}$ management is crucial to producing a high-yielding, good-quality potato crop. Excess $\mathrm{N}$ has been shown to delay tuberization and reduce yields in areas with short growing seasons (Gardner, 1975; Gunasena and Harris, 1971; Hunnius and Munzert, 1979; Kleinkopf et al., 1981; Krauss, 1985; Moorby and Milthorpe, 1975; Westermann and Kleinkopf, 1985). Insufficient $N$ results in early senescence and reduces yields (Westermann and Kleinkopf, 1985).

Petiole nitrate analysis has become an important $\mathrm{N}$ management tool for potato crops, especially in the northwestern United States (Doll et al., 1971; Gardner, 1975; Kleinkopf et al., 1984; Lorenz, 1954; Ram et al., 1979; Terman et al., 1951; Westermann and Kleinkopf, 1985). Extensive work has been done to establish and document the petiole $\mathrm{NO}_{3}-\mathrm{N}$ concentration (PNC) critical levels for 'Russet Burbank' (Gardner, 1975; Kleinkopf et al., 1984; Westermann and Kleinkopf, 1985). Recently, similar research has been done for other cultigens (MacMurdo et al., 1988; Porter and Sisson, 1991, 1993; Williams and Maier, 1990); however, the effect of genotype on PNCs is not well understood. Most growers and agribusinesses use generalized criticallevel recommendations (Geraldson et al., 1973)

Received for publication 9 Apr. 1993. Accepted for publication 19 Oct. 1993. Idaho Agricultural Experiment Station manuscript no. 92745. This research was funded by Cooperative State Research Service grant no. 92-34141-6957. The cost of publishing this paper was defrayed in part by the payment of page charges. Under postal regulations, this paper therefore must be hereby marked advertisement solely to indicate this fact.

${ }^{1}$ Former Graduate Student. Current address: Soil Conservation Service, P.O. Box 333, Roosevelt, UT 84066. or those levels established for 'Russet Burbank', regardless of the cultigen in production. Some researchers recognize that critical levels are cultigen dependent (Porter and Sisson, 1991), but there is a lack of information defining the influence of genotype on PNCs.

Our objectives were to 1) measure and compare PNCS among seven cultigens treated with four $\mathrm{N}$ rates, and 2) investigate the interactions, with respect to PNC, between cultigens and other factors, including $\mathrm{N}$ fertilizer rate, growing season, and sampling date.

\section{Materials and Methods}

This study was conducted from 1986 to 1988 on a Declo silt-loam (coarse-loamy, mixed, mesic Xerollic Calciorthid) at the Aberdeen Research and Extension Center in Aberdeen, Idaho. We used a split-plot field design (four replications) with four $\mathrm{N}$ rates $(0$, 140,280 , and $420 \mathrm{~kg} \cdot \mathrm{ha}^{-1}$ ) as main plots. 'Russet Burbank', 'Butte', 'Frontier Russet', 'Ranger Russet', 'Gemchip', and two selections from the Aberdeen U.S. Dept. of Agriculture-Agriculture Research Service potato breeding program, A76147-2 and A72685-2 were arranged as subplots. These seven cultigens represent a wide range of maturity and genetic backgrounds. Single-row plots were buffered on each side with a row of 'Russet Burbank'. Rows were $0.9 \mathrm{~m}$ apart with a 0.25 $\mathrm{m}$ in-row spacing. Plot length was $9.1 \mathrm{~m}$ in 1986 and $12.2 \mathrm{~m}$ in 1987 and 1988. Planting dates were 1 May 1986, 1 May 1987, and 27 Apr. 1988. Harvest dates were 9 Oct. 1986,30 Sept. 1987, and 11 Oct. 1988. Plots were irrigated every 6 to 10 days using solid-set sprinklers to maintain the soil moisture $>60 \%$ field capacity. 4-Amino-6-tert-butyl-3-
(methylthio)-as-triazin5(4H)-one(meribuzin) applied at $0.56 \mathrm{~kg}$ a.i./ha was used for weed control. One-quarter of each $\mathrm{N}$ treatment (amonium nitrate) was applied preplant, and one-eighth was applied thereafter at 2-week intervals as one of six sidedress applications. Soil samples were taken from the first $60 \mathrm{~cm}$ of the soil profile before preplant fertilization and analyzed for $\mathrm{NO}_{3}-\mathrm{N}$ by the Univ. of Idaho analytical laboratory using the method described by Keeney and Nelson (1982). Average residual $\mathrm{NO}_{3}-\mathrm{N}$ concentrations $\left(\mathrm{mg} \cdot \mathrm{kg}^{-1}\right)$ were determined for the 0 -to $30-\mathrm{cm}$ and $31-$ to 60-cm soil depths, respectively: 6.8 and 7.8 in 1986,22.7 and 20.9 in 1987, and 8.0 and 9.9 in 1988. In 1986 and 1988, the residual $\mathrm{NO}_{3}-\mathrm{N}$ concentrations were typical for the small-grain potato rotation used at the plot location; the

Table 1. Analysis of variance table for potato petiole $\mathrm{NO}_{3}-\mathrm{N}$ concentrations over years.

\begin{tabular}{|c|c|c|c|}
\hline $\begin{array}{l}\text { Source of } \\
\text { variations }\end{array}$ & df & $\mathrm{MS}^{\mathrm{z}}$ & $\begin{array}{c}\text { Observed } \\
\text { F }\end{array}$ \\
\hline \multicolumn{4}{|l|}{ Main plot } \\
\hline Replication (R) & 3 & 463 & 3.1 \\
\hline Year $(\mathrm{Y})$ & 2 & 1574 & $10.5^{*}$ \\
\hline Error a & 6 & 150 & -- \\
\hline \multicolumn{4}{|l|}{ Subplot } \\
\hline Time (T) & 3 & 4343 & $353.6^{* *}$ \\
\hline $\mathrm{T} \times \mathrm{Y}$ & 6 & 58 & $4.7^{* *}$ \\
\hline Error b & 27 & 12 & --- \\
\hline \multicolumn{4}{|l|}{ Sub-subplot } \\
\hline$N$ rate $(N)$ & 3 & 7338 & $517.6^{* *}$ \\
\hline $\mathrm{N} \times \mathrm{Y}$ & 6 & 232 & $16.4^{* *}$ \\
\hline $\mathrm{N} \times \mathrm{T}$ & 9 & 204 & $14.4^{* *}$ \\
\hline $\mathrm{N} \times \mathrm{Y} \times \mathrm{T}$ & 18 & 35 & $2.5^{* *}$ \\
\hline Error c & 108 & 14 & --- \\
\hline \multicolumn{4}{|l|}{ Sub-sub-subplot } \\
\hline Cultigen (C) & 6 & 1610 & $361.7^{* *}$ \\
\hline $\mathrm{C} \times \mathrm{Y}$ & 12 & 74 & $16.6^{* *}$ \\
\hline $\mathrm{C} \times \mathrm{T}$ & 18 & 18 & $4.1^{* *}$ \\
\hline $\mathrm{C} \times \mathrm{N}$ & 18 & 49 & $11.1^{* *}$ \\
\hline $\mathrm{C} \times \mathrm{Y} \times \mathrm{T}$ & 36 & 7 & $1.6^{*}$ \\
\hline $\mathrm{C} \times \mathrm{Y} \times \mathrm{N}$ & 36 & 6 & $1.5^{*}$ \\
\hline $\mathrm{C} \times \mathrm{T} \times \mathrm{N}$ & 54 & 11 & $2.4^{* *}$ \\
\hline $\mathrm{C} \times \mathrm{Y} \times \mathrm{N} \times \mathrm{T}$ & 108 & 3 & 0.8 \\
\hline Error d & 864 & 4 & --- \\
\hline Total & 1343 & & \\
\hline
\end{tabular}

${ }^{2} \mathrm{MS}=$ mean square; values shown as mean square $\times$ $10^{-6}$.

****Significant at $P \leq 0.05$ or 0.01 , respectively.

Table 2. Potato petiole $\mathrm{NO}_{3}-\mathrm{N}$ concentration (PNC) averaged over all other variables for three trial years, four sampling dates, and four $\mathrm{N}$ rates.

\begin{tabular}{lc}
\hline Variable & PNC (mg-liter ${ }^{-1}$ \\
\hline Year & 14,900 \\
1986 & 12,600 \\
1987 & 11,200 \\
1988 & 2,000 \\
LSD $_{0.05}$ & \\
Sample time (DAP) & \\
67 & 17,900 \\
81 & 12,900 \\
95 & 10,800 \\
109 & 9,900 \\
LSD & 605 \\
N rate $\left.^{2} \mathrm{~kg}^{2} \mathrm{ha}^{-1}\right)$ & 600 \\
0 & \\
140 & 6,700 \\
280 & 12,000 \\
420 & 15,500 \\
LSD $_{0.05}$ & 17,400 \\
\hline$D_{4}$ & 600 \\
\hline
\end{tabular}

${ }^{2} \mathrm{DAP}=$ days after planting. 
concentrations in 1987 were atypically high.

Leaf petiole samples were taken $67,81,95$, and 109 days after planting (DAP). The first date was near the onset of tuber initiation, and the last was just before senescence. The petiole from the youngest fully expanded (fourth) leaf was sampled according to Univ. of Idaho recommendations (Kleinkopf et al., 1984). The petioles were dried at $40 \mathrm{C}$ and ground to pass through a $0.65-\mathrm{mm}$ mesh screen. Nitrate$\mathrm{N}$ analysis was accomplished using the nitro salicylic acid method described by Cataldo et al. (1975).

Analysis of variance (ANOVA) was completed for yield and PNC, and all main and interaction effects were partitioned. Regression equations were computed for the PNC of each cultigen as related to sampling date. The conditional error method was used to test for coincidence among the regression equations. Additional analysis was performed on a data subset consisting of the 1988 trial. Regression equations were computed for each cultigen relating yield to $\mathrm{N}$ rate, and the predicted optimum $\mathrm{N}$ rate for maximum yield was estimated. A regression equation for each cultigen was computed for the closest applied $\mathrm{N}$ rate, and the equations were tested for coincidence.

\section{Results and Discussion}

All main effects and interactions had a significant $(P \leq 0.05)$ influence on PNCs with the exception of the four-way interaction cultigen $\times$ year $\times$ sampling time $\times \mathrm{N}$ rate (Table 1 ). PNCs were highest in 1986 and lowest in 1988 (Table 2). Differences in residual soil $\mathrm{NO}_{3}-\mathrm{N}$ concentrations, which were highest in 1987 , did not appear to account for differences between years. The differences between years likely were due to unidentified environmental factors that influenced growth rate and maturity stage at any one sampling time.

As the season progressed, PNCs declined, resulting in a significant sampling time effect. This seasonal decline has been well documented and is normally associated with plant aging (Gardner, 1975; Kleinkopf et al., 1984; Porter and Sisson, 1991). The uniqueness of each growing season resulted in a significant sampling time $\times$ year interaction. Nitrogen rate and its interaction with year and sampling time were also significant. Increasing $\mathrm{N}$ application rates resulted in correspondingly higher PNCs. The unique growing conditions within each year also had some effect on the $\mathrm{N}$ rate response. The sampling time $\times \mathrm{N}$ rate interaction was due to a more rapid decline in PNCs over time at the lower application rates than at the higher rates (Figs. 1-4).

Given our objectives, the effects involving cultigen were of greatest interest to us. Cultigen and all associated two- and three-way interactions were significant, indicating that at least one cultigen had higher or lower PNCs and responded differently to conditions imposed by growing year, $\mathrm{N}$ rate, and sampling time. To differentiate between cultigens, PNC data were combined for the 3 years and a regression equation was computed for each cultigen-N rate combination (Table 3 ). In

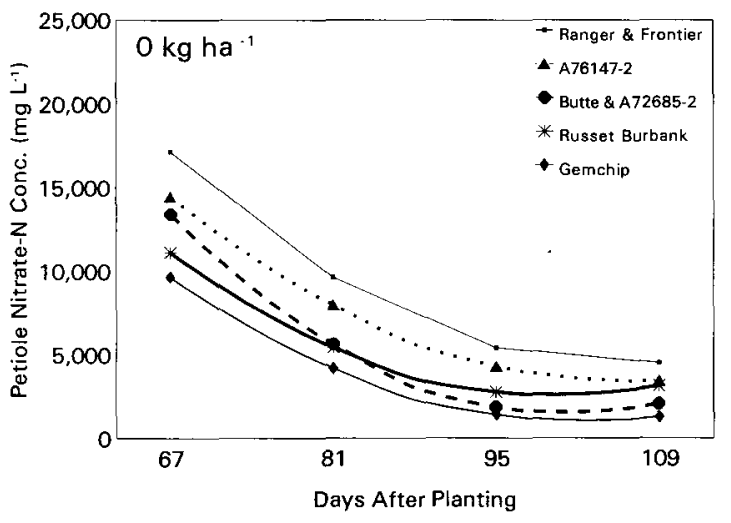

Fig. 1. Petiole $\mathrm{NO}_{3}-\mathrm{N}$ concentration of seven potato cultigens with no added $\mathrm{N}$ fertilizer. Samples taken at 67,81,95, and 109 days after planting. Data were combined for trials conducted from 1986 to 1988.

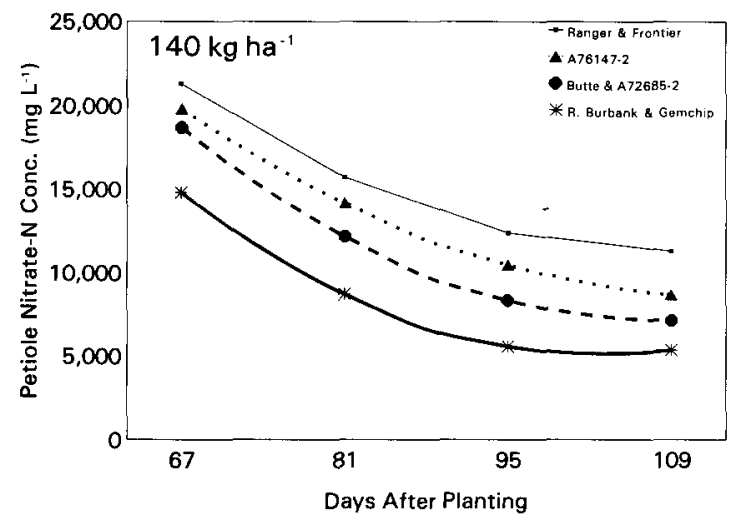

Fig. 2. Petiole $\mathrm{NO}_{3}-\mathrm{N}$ concentration of seven potato cultigens with $140 \mathrm{~kg} \mathrm{~N} /$ ha added. Samples taken at 67 , 81,95, and 109 days after planting. Data were combined for trials conducted from 1986 to 1988.

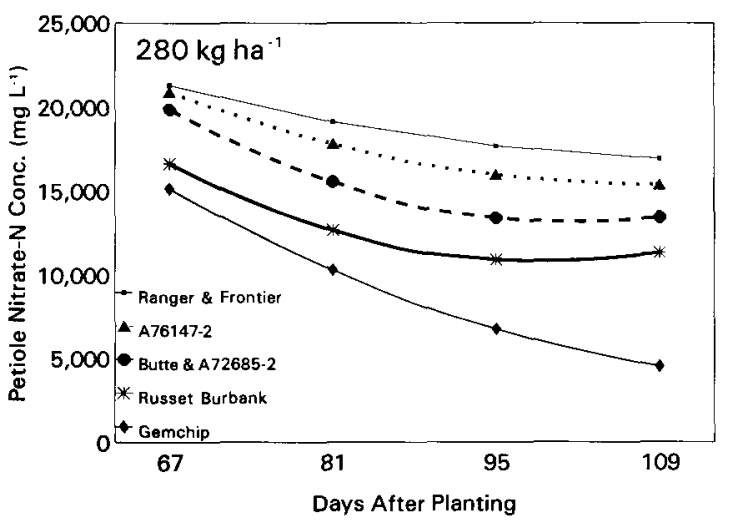

Fig. 3. Petiole $\mathrm{NO}_{3}-\mathrm{N}$ concentrations of seven potato cultigens with $280 \mathrm{~kg} \mathrm{~N} / \mathrm{ha}$ added. Samples taken at $67,81,95$, and 109 days after planting. Data were combined for trials conducted from 1986 to 1988.

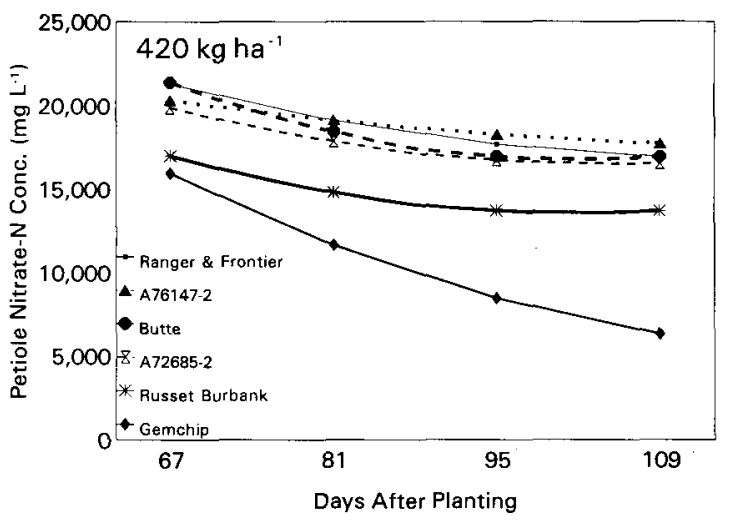

Fig. 4. Petiole $\mathrm{NO}_{3}-\mathrm{N}$ concentration of seven potato cultigens with $420 \mathrm{~kg} \mathrm{~N} /$ ha added. Samples taken at 67 , 81,95, and 109 days after planting. Data were combined for trials conducted from 1986 to 1988. 
most cases, a quadratic equation gave the best fit, and to simplify comparisons, this model was used for all equations. The equations were tested for coincidence and were plotted (Figs. 1-4)

At all $\mathrm{N}$ rates, except at $420 \mathrm{~kg} \cdot \mathrm{ha}$, where 'Frontier Russet' had a nonsignificant regression equation, 'Frontier Russet' and 'Ranger Russet' equations were coincident. Coincidence also occurred for 'Frontier Russet' and A76147-2 at $0 \mathrm{~kg} \cdot \mathrm{ha}^{-1}$; for A76147-2 and 'Butte' at 0 and $140 \mathrm{~kg} \cdot \mathrm{ha}^{-1}$; for 'Butte' and A72685-2 at 0, 140, and $280 \mathrm{~kg} \cdot \mathrm{ha}^{-1}$; and for 'Russet Burbank' and 'Gemchip' at 140 $\mathrm{kg} \cdot \mathrm{ha}^{-1}$. The remaining equations, within $\mathrm{N}$ rates, were distinct, supporting the ANOVA evidence that genotype influenced PNC and its response to imposed and environmental factors.

Overall, 'Frontier Russet' and 'Ranger Russet' had the highest PNCS followed by A76147-2, 'Butte', A72685-2, 'Russet Burbank', and 'Gemchip' (Table 4). Averaged across sampling time and $\mathrm{N}$ rate, the cultigen rank within each year was consistent. The only rank shifts were among cultigens with consistently coincidental regression equations. Even though rank was consistent, the significant cultigen $\times$ year interaction indicated that PNC response across years was different for some cultigens than for others. This result may be due in part to the sampling procedure, which was done on a calendar basis rather than according to growth stage. This interaction suggests that PNC-based N-status diagnosis can be complex and possibly less reliable when dealing with more than one cultigen.

Distinct regression equations and significant interactions provided evidence that genotypes were unique with respect to seasonal PNCs at different $\mathrm{N}$ rates. When no $\mathrm{N}$ was applied, the decline rate over the season for 'Frontier Russet' and 'Ranger Russet' was similar to that of 'Gemchip', but the $\mathrm{NO}_{3}-\mathrm{N}$ concentration for 'Gemchip' was lower at the first sampling and declined to a lower concentration at the last sampling. With $420 \mathrm{~kg} \mathrm{~N} / \mathrm{ha}$ at the first sampling, 'Ranger Russet' and 'Frontier Russet' had PNCs near 22,000 $\mathrm{mg} \cdot \mathrm{liter}^{-1}$; although at the last sampling, the concentration had dropped slightly to 19,500 mg.liter ${ }^{-1}$. In contrast, 'Gemchip' started at $\approx 16,000 \mathrm{mg} \cdot \mathrm{liter}^{-1}$ and declined rapidly to just $>6000 \mathrm{mg} \cdot$ liter $^{-1}$. The other cultigen responses at the other $\mathrm{N}$ rates were intermediate to those described. Based on the tests for coincidence and plots of regression lines, the cultigens can be divided into four response types. The first type is typified by 'Frontier Russet' and 'Ranger Russet'; the second by A76147-2, 'Butte', and A72685-2; the third by 'Russet Burbank'; and the fourth by 'Gemchip'.

The large differences in cultigen PNCs as a result of the different $\mathrm{N}$ rates were not necessarily accompanied by large differences in yield (Table 5). Averaged across years, each cultigen's yield was lower when no $\mathrm{N}$ was applied but similar among the three treatments with added N. As with PNCs, all treatment interactions except year $\times \mathrm{N}$ rate $\times$ cultigen were significant. Additional analyses were completed to determine if the differences in cultigen PNC response were present at optimal $\mathrm{N}$ rate when a large $\mathrm{N}$ influence is present for yield.

Regression equations were computed relating yield to $\mathrm{N}$ rate for the 1988 data. The two previous years' data were not included to

avoid confounding year effects, and 1988 was chosen because that trial had the greatest differences in yield between $\mathrm{N}$ rates. The regression equations were used to predict the $\mathrm{N}$ rate for maximum yield. For all but A72685-2, the optimum $\mathrm{N}$ rate was $280 \mathrm{~kg} \cdot \mathrm{ha}^{-1}$. A72685-2 did not have a significant yield $\times \mathrm{N}$ rate regression equation but appeared to reach a yield

Table 3. Regression equations relating potato petiole $\mathrm{NO}_{3}-\mathrm{N}$ concentration to number of days after planting (DAP). ${ }^{2}$

\begin{tabular}{|c|c|c|c|}
\hline $\begin{array}{l}\mathrm{N} \text { rate } \\
\left(\mathrm{kg}^{2} \cdot \mathrm{ha}^{-1}\right)\end{array}$ & Cultigen & Equation ${ }^{y}$ & $r^{2}$ \\
\hline \multirow[t]{7}{*}{0} & Frontier Russet & $y=17300-640 x+7.5 x^{2} A B$ & $0 . \overline{53^{* *}}$ \\
\hline & Ranger Russet & $y=17100-670 x+0.4 x^{2} A$ & $0.44^{* *}$ \\
\hline & A76147-2 & $y=14500-570 x+7.2 x^{2} B C$ & $0.44^{* *}$ \\
\hline & Butte & $y=13800-660 x+9.1 x^{2} C D$ & $0.61^{* *}$ \\
\hline & A72685-2 & $y=13100-740 x+11.3 x^{2} D$ & $0.68^{* *}$ \\
\hline & Russet Burbank & $y=11100-510 x+7.7 x^{2} E$ & $0.45^{* *}$ \\
\hline & Gemchip & $y=9600-480 x+6.8 x^{2} F$ & $0.59^{* *}$ \\
\hline \multirow[t]{7}{*}{140} & Frontier Russet & $y=20500-390 x+3.7 x^{2} A$ & $0.42^{* *}$ \\
\hline & Ranger Russet & $y=22100-570 x+7.7 x^{2} A$ & $0.48^{* *}$ \\
\hline & A76147-2 & $y=19800-470 x+4.9 x^{2} B$ & $0.56^{* *}$ \\
\hline & Butte & $y=19100-520 x+5.6 x^{2} B C$ & $0.52^{* *}$ \\
\hline & A72685-2 & $y=18300-600 x+7.9 x^{2} C$ & $0.51^{* *}$ \\
\hline & Russet Burbank & $y=14700-510 x+7.9 x^{2} D$ & $0.48^{* *}$ \\
\hline & Gemchip & $y=14900-570 x+7.1 x^{2} D$ & $0.79^{* *}$ \\
\hline \multirow[t]{7}{*}{280} & Frontier Russet & $y=21200-150 x+1.0 x^{2} A$ & $0.28^{* *}$ \\
\hline & Ranger Russet & $y=21500-210 x+2.7 x^{2} A$ & $0.31^{* *}$ \\
\hline & A76147-2 & $y=20900-260 x+3.1 x^{2} B$ & $0.36^{* *}$ \\
\hline & Butte & $y=20600-430 x+6.3 x^{2} C$ & $0.49^{* *}$ \\
\hline & A72685-2 & $y=19100-340 x-4.7 x^{2} C$ & $0.39^{* *}$ \\
\hline & Russet Burbank & $y=16600-360 x+5.6 x^{2} D$ & $0.35^{* *}$ \\
\hline & Gemchip & $y=15100-390 x+3.3 x^{2} E$ & $0.70^{* *}$ \\
\hline \multirow[t]{7}{*}{420} & Frontier Russet & $y=21900-60 x+0.5 x^{2}$ & $0.04^{\mathrm{Ns}}$ \\
\hline & Ranger Russet & $y=22500-200 x+2.4 x^{2} A$ & $0.37^{* *}$ \\
\hline & A76147-2 & $y=20300-100 x+0.8 x^{2}$ & $0.11^{\mathrm{ss}}$ \\
\hline & Butte & $y=21400-260 x+3.7 x^{2} B$ & $0.34^{* *}$ \\
\hline & A72685-2 & $y=19900-180 x+2.3 x^{2} C$ & $0.41^{* *}$ \\
\hline & Russet Burbank & $y=17000-190 x+2.7 x^{2} D$ & $0.36^{* *}$ \\
\hline & Gemchip & $y=16000-340 x+2.7 x^{2} E$ & $0.73^{* *}$ \\
\hline
\end{tabular}

'Regression equations were computed using $67 \mathrm{DAP}$ as the $\mathrm{x}$-axis point of origin.

'Each possible pair combination of regression equations within an $\mathrm{N}$ rate was tested for coincidence using the method of conditional error. Equations within each $\mathrm{N}$ rate followed by the same letter are not considered statistically $(P \leq 0.05)$ different.

Ns,$* *$ Nonsignificant or significant at $P<0.01$, respectively.

Table 4. Petiole $\mathrm{NO}_{3}-\mathrm{N}$ concentration (PNC) and petiole $\mathrm{NO}_{3}-\mathrm{N}$ rank, averaged across $\mathrm{N}$ treatments and sampling dates, for seven potato cultigens in 3 years.

\begin{tabular}{lcccc}
\hline Cultigen & \multicolumn{1}{c}{1986} & 1987 & 1988 \\
PNC (rank) & PNC (rank) & PNC (rank) & $\begin{array}{c}\text { Avg 3-year } \\
\text { PNC (rank) }\end{array}$ \\
\hline Frontier Russet & $19,000(1)$ & $15,000(2)$ & $13,600(1)$ & $15,900(1)$ \\
Ranger Russet & $18,300(2)$ & $16,100(1)$ & $13,400(2)$ & $15,900(1)$ \\
A76147-2 & $16,700(3)$ & $14,500(3)$ & $11,800(3)$ & $14,300(3)$ \\
Butte & $15,800(4)$ & $12,600(4)$ & $11,000(5)$ & $13,100(4)$ \\
A72685-2 & $14,300(5)$ & $11,600(5)$ & $11,200(4)$ & $12,400(5)$ \\
Russet Burbank & $12,300(6)$ & $10,700(6)$ & $9,100(6)$ & $10,700(6)$ \\
Gemchip & $7,900(7)$ & $7,600(7)$ & $8,300(7)$ & $7,900(7)$ \\
LSD & 700 & 900 & 600 & 400 \\
\hline
\end{tabular}

Table 5. Yield of seven potato cultigens at each of four $\mathrm{N}$ application rates averaged across years.

\begin{tabular}{|c|c|c|c|c|c|}
\hline \multirow[b]{2}{*}{ Cultigen } & \multicolumn{4}{|c|}{$\mathrm{N}$ rate $\left(\mathrm{kg} \cdot \mathrm{ha} \mathrm{a}^{-1}\right)^{z}$} & \multirow{2}{*}{$\begin{array}{c}\text { Cultigen } \\
\text { mean }\end{array}$} \\
\hline & 0 & 140 & 280 & 420 & \\
\hline \multicolumn{6}{|c|}{$M g \cdot h a^{-I}$} \\
\hline Frontier Russet & 33.4 & 34.7 & 36.6 & 32.3 & 34.3 \\
\hline Ranger Russet & 40.2 & 45.4 & 46.1 & 47.1 & 44.7 \\
\hline A76147-2 & 48.0 & 53.2 & 56.6 & 54.6 & 53.1 \\
\hline Butte & 42.8 & 45.7 & 47.4 & 47.7 & 45.9 \\
\hline A72685-2 & 42.7 & 47.8 & 43.8 & 47.5 & 45.5 \\
\hline Russet Burbank & 39.7 & 43.5 & 43.2 & 43.2 & 42.4 \\
\hline Gemchip & 42.3 & 46.8 & 44.4 & 47.2 & 45.2 \\
\hline $\mathrm{N}$ rate mean & 41.3 & 45.3 & 45.5 & 45.7 & \\
\hline
\end{tabular}


Table 6. Total potato tuber yield separated by $\mathrm{N}$ rate, regression equations relating $\mathrm{N}$ rate to yields, and predicted $\mathrm{N}$ rate for maximum yields for seven potato cultigens in the 1988 trial.

\begin{tabular}{|c|c|c|c|c|c|c|c|c|}
\hline \multirow[b]{3}{*}{ Cultigen } & \multicolumn{5}{|c|}{ Total yield $\left(\mathrm{Mt} \cdot \mathrm{ha}^{-1}\right)$} & & & \multirow{3}{*}{$\begin{array}{l}\text { Predicted } \\
\mathrm{N} \text { rate for } \\
\text { max. yield } \\
\left(\mathrm{kg} \cdot \mathrm{ha}^{-1}\right)\end{array}$} \\
\hline & \multicolumn{5}{|c|}{$\mathrm{N}$ rate $\left(\mathrm{kg} \cdot \mathrm{ha}^{-1}\right)$} & \multicolumn{2}{|l|}{ Regression } & \\
\hline & o & 140 & 280 & 420 & Mean & Equation & $r^{2}$ & \\
\hline Frontier Russet & 34.7 & 45.1 & 45.0 & 39.7 & 41.1 & $\mathrm{y}=34.94+0.10 \mathrm{x}-0.00020 \mathrm{x}^{2}$ & $0.63 * *$ & 250 \\
\hline Ranger Russet & 38.3 & 51.9 & 51.8 & 50.6 & 48.2 & $y=38.97+0.11 x-0.00019 x^{2}$ & $0.69 * *$ & 289 \\
\hline A76147-2 & 42.6 & 59.2 & 66.3 & 56.6 & 56.2 & $y=42.25+0.18 x-0.00034 x^{2}$ & $0.77 * *$ & 266 \\
\hline Butte & 41.1 & 48.7 & 55.2 & 52.9 & 49.3 & $y=40.70+0.08 x-0.00013 x^{2}$ & $0.53 * *$ & 307 \\
\hline A72685-2 & 38.5 & 49.7 & 47.0 & 50.3 & 46.4 & $y=39.51+0.07 x-0.00010 x^{2}$ & $0.35^{\mathrm{NS}}$ & --- \\
\hline Russet Burbank & 37.4 & 45.2 & 47.3 & 44.6 & 43.6 & $y=37.43+0.07 x-0.00013 x^{2}$ & $0.56 * *$ & 273 \\
\hline Gemchip & 39.8 & 54.8 & 48.5 & 54.9 & 49.5 & $y=41.49+0.07 x-0.00011 x^{2}$ & $0.47 *$ & 314 \\
\hline Mean & 38.9 & 50.7 & 51.6 & 49.9 & & & & \\
\hline
\end{tabular}

${ }^{\overline{2}} \mathrm{LSD}_{0.05}$ for total yield: cultigen $=2.9 ; \mathrm{N}$ rate $=2.2 ;$ interaction $=5.8$.

ss, $*$,**Nonsignificant or significant at $P \leq 0.05$ or 0.01 , respectively.

Table 7. Regression equations for relating potato petiole $\mathrm{NO}_{3}-\mathrm{N}$ concentrations to number of days after planting (DAP) in the 1988 trial:

\begin{tabular}{llr}
\hline \hline & \multicolumn{1}{c}{ Regression } \\
\cline { 2 - 3 } Cultigen & \multicolumn{1}{c}{ Equation $^{y}$} & $r^{2}$ \\
\hline Frontier Russet & $\mathrm{y}=21400-230 \mathrm{x}+0.6 \mathrm{x}^{2} \mathrm{~A}$ & $0.84^{* * *}$ \\
Ranger Russet & $\mathrm{y}=21700-350 \mathrm{x}+3.9 \mathrm{x}^{2} \mathrm{~A}$ & $0.88^{* *}$ \\
A76147-2 & $\mathrm{y}=20900-480 \mathrm{x}+6.8 \mathrm{x}^{2} \mathrm{~B}$ & $0.84^{* *} 1$ \\
B u t t & $\mathrm{y}=20300-660 \mathrm{x}+10.4 \mathrm{x}^{2} \mathrm{C}$ & $0.80^{* *}$ \\
A72685-2 & $\mathrm{y}=19400-460 \mathrm{x}+6.4 \mathrm{x}^{2} \mathrm{BC}$ & $0.66^{* *}$ \\
Russet Burbank & $\mathrm{y}=16400-500 \mathrm{x}+7.6 \mathrm{x}^{2} \mathrm{D}$ & $0.76^{* *}$ \\
Gemchip & $\mathrm{y}=16900-500 \mathrm{x}+4.7 \mathrm{x}^{2} \mathrm{E}$ & $0.94^{* *}$ \\
\hline
\end{tabular}

${ }^{2}$ Regression equations were computed using 67 DAP as the point of origin on the $x$ axis.

"A11 pair combinations of regression equations were tested for coincidence using the method of conditional error. Equations followed by the same letter are not considered statistically $(\boldsymbol{P} \leq 0.05)$ different.

Ns,$* *$ Nonsignificant or significance at $P \leq 0.01$, respectively.

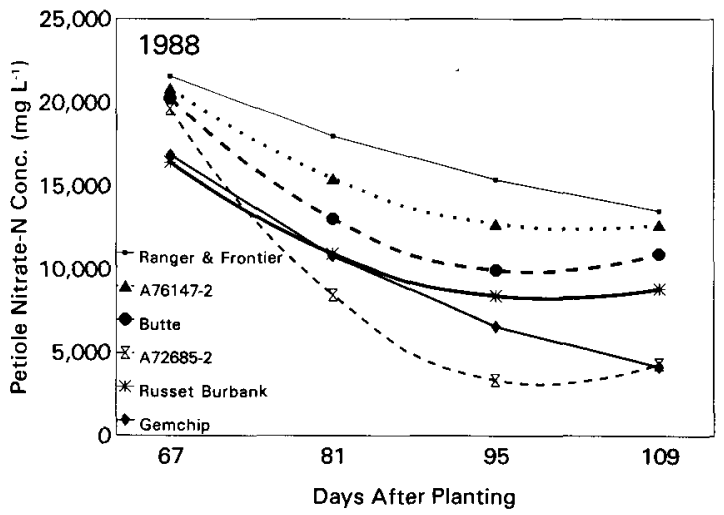

Fig. 5. Petiole $\mathrm{NO}_{3}-\mathrm{N}$ concentration of seven potato cultigens grown in 1988 at the $\mathrm{N}$ rate nearest the predicted optimum. Petiole samples were taken 67, 81,95, and 109 days after planting.

plateau at $140 \mathrm{~kg} \cdot \mathrm{ha}^{-1}$ (Table 6). This rate was chosen as optimum based on an inspection of the yield data.

For the optimum applied $\mathrm{N}$ rate, a regression equation was calculated for each cultigen relating PNC to sampling time (Table 7). The resulting seven equations were tested for coincidence and plotted (Fig. 5). Equations for 'Ranger Russet' and 'Frontier Russet' were coincident and considered identical. All other equations were distinct, suggesting that, with the one exception, each cultigen has its own unique $\mathrm{PNC}$ response at optimum $\mathrm{N}$ application rates within a growing season.

The diverse PNC responses of the seven cultigens in this study were not completely unexpected given the heterogeneous nature of potatoes. However, the magnitude of the differences between cultigens may have important implications for PNC use to manage $\mathrm{N}$ fertility in potatoes. Although this study was not designed to determine PNC critical levels for any of the cultigens, it provides evidence that genotype may influence those critical levels. These differences between cultigens are important only if they exist under $\mathrm{N}$-availability conditions considered sufficient for potato production. 'Russet Burbank' has been the subject of many PNC critical level studies. Kleinkopf et al. (1984) documented the critical PNC of 'Russet Burbank' through the tuber growth phase at $15,000 \mathrm{mg} \cdot$ liter $^{-1}$. For comparison, the end of the tuber growth phase in this study always fell between the 95 and 109 DAP sampling dates. Kleinkopf et al.'s (1984) recommendation agrees with the work of Porter and Sisson (1991). They found the sufficient PNC for maximum yield to be 13,000-20,000 mg.liter ${ }^{-1}$ at 30 DAP; 9000 $19,000 \mathrm{mg} \cdot$ liter $^{-1}$ at 80DAP; and 7000-16,000 $\mathrm{mg} \cdot \mathrm{liter}^{-1}$ at 100 DAP. Using these two researchers' criteria, the optimal $\mathrm{N}$ rate for 'Russet Burbank' would fall between 140 and 280 $\mathrm{kg} \cdot \mathrm{ha}^{-1}$. In this N-rate range, there are distinct responses in PNCs for the cultigens in this study.

'Gemchip' was unique in respect to its seasonal PNC response compared to the other cultigens. The $\mathrm{N}$ rates used in this study ranged from deficient to excessive. Under these extreme conditions, 'Gemchip' PNCs were largely unresponsive, beginning the season lower than the other cultigens and rapidly declining, regardless of $\mathrm{N}$ rate. For most of the cultigens, $\mathrm{N}$ rate largely dictated $\mathrm{PNC}$, but for 'Gemchip' the timing of the sample collection was the most significant contributing factor. Given this response, using the common practice of seasonal petiole sampling for $\mathrm{N}$ management may not be successful for a cultigen such as 'Gemchip'.

\section{Literature Cited}

Cataldo, D. A., M. Haroon, L.E. Schrader, and U.L. Youngs. 1975. Rapid colorimetric determination of nitrate in plant tissue by nitration of salicylic acid. Commun. Soil Sci. Plant Anal. 6:71-80.

Doll, E.C., D.R. Christensen, and A.R. Wolcott. 1971. Potato yields as related to nitrate levels in petioles and soils, Amer. Potato J. 48:105-112,

Gardner, B.R. 1975. Petiole analysis and the nitrogen fertilization of Russet Burbank potatoes. Amer. Potato J. 52: 195-200.

Geraldson, C.M., G.R. Klacan, and O.A. Lorenz. 1973. Plant analysis as an aid in fertilizing vegetable crops, p. 365-370. In: L.M. Walsh (cd.). Soil testing and plant analysis. Soil Sci. Soc. Amer., Madison, Wis.

Gunasena, H.P.M. and P.M. Harris. 1971. The effect of CCC, nitrogen, and potassium on the growth and yield of two varieties of potatoes. J. Agr. Sci 6:33-52.

Hunnius, W. and M. Munzert. 1979. Effect of single and multiple applications of different quantity of nitrogen to the potato crop in relation to variety. Potato Res. 22:289-304.

Keeney, D.R. and D.W. Nelson. 1982. Nitrogen: In organic forms, p. 676-682. In: A.L. Page, R.H. Miller, and D.R. Keeney (eds.). Methods of soil analysis: Part 2-Chemical and microblological properties. (2nd ed.). Amer. Soc. Agron., Madison, Wis.

Kleinkopf, G. E., G.D. Kleinschmidt, and D.T. Westermann. 1984. Tissue analysis: A guide to nitrogen fertilization for Russet Burbank pota- 
toes. Univ. of Idaho Current Information Series 743.

Kleinkopf, G.E., D.T. Westermann, and R.B. Dwelle. 1981. Dry matter production and nitrogen utilization by six potato cultigens. Agron. J. 73:799802.

Krauss, A. 1985. Potato physiology, p. 209-231.“In: P. Lee (ed.). Interaction of nitrogen nutrition, phytohormones, and tuberization. Academic, New York.

Lorenz, O.A. 1954. Potato fertilizer experiments in California. Calif. Agr. Expt. Sta. Bul. 744.

McMurdo, W., R.K. Prange, and R. Vienot. 1988. Nitrogen fertilization and petiole tissue testing in production of while seed tubers of the potato cultigens Sebago and Atlantic. Can. J. Plant Sci. 68:901-905

Moorby, J. and F.L. Milthorpe. 1975. Potato, p 225-257. In: L.T. Evans (ed.). Crop physiology: Some case histories. Cambridge Univ. Press, London.

Porter, G.A. and J.A. Sisson. 1991. Petiole nitrate content of Maine-grown Russet Burbank and Shepody potatoes in response to varying nitrogen rate. Amer. Potato J. 68:493-505.

Porter, G.A. and J.A. Sisson. 1993. Yield, market quality and petiole nitrate concentration of nonirrigated Russet Burbank and Shepody potatoes in response to sidedressed nitrogen. Amer. Potato J. 70:101-116.
Ram, B., R.P. Singh, and S.P. Uniyaf. 1979. The influence of rates of nitrogen application on the performance of potato varieties. J. Indian Potato Assn. 6:220-223.

Terman, G.L., A. Hawkins, C.E. Cunningham, and R.A. Strachtemeyer. 1951. Rate, placement, and source of nitrogen for potatoes in Maine. Maine Agr. Expt. Sta. Bul. 490.

Westermann, D.T. and G.E. Kleinkopf. 1985. Nitrogen requirements of potatoes. Agron. J. 77:616 621.

Williams, C.M.J. and N.A. Maier. 1990. Determination of the nitrogen status of irrigated potato crops. I. Critical nutrient ranges for nitratenitrogen in petioles. J. Plant Nutr. 13:971-984. 